\title{
The Comparison of Post Coronary Artery Bypass Graft Functional Capacity between High Intensity Interval Training and Moderate Continuous Intensity Aerobic Exercise in Phase II Cardiac Rehabilitation Patients
}

\author{
Dini Fitriani ${ }^{1 *}$, Irma Ruslina Defi ${ }^{1}$, Sunaryo B Sastradimaja ${ }^{1}$, Badai B Tiksnadi ${ }^{2}$
}

1 Department of Physical Medicine and Rehabilitation, Dr. Hasan Sadikin General Hospital, Faculty of Medicine, University of Padjajaran, Bandung, Indonesia

2 Department of Cardiology, Dr. Hasan Sadikin General Hospital, Faculty of Medicine, University of Padjajaran, Bandung, Indonesia

\begin{abstract}
Introduction: Increased aerobic exercise capacity appears to reduce all-cause mortality and cardiovascular mortality. Aerobic exercise improves functional capacity (FC) is strongly recommended. However, evidence regarding the most efficient exercise intensity for patients post Coronary Artery Bypass Surgery $(\mathrm{CABG})$ is still limited. This study aimed to assess the effects of high-intensity interval exercise (HIIT) compared to moderate-continous intensity exercise (MCT) for increasing FC in patients post CABG.

Methods: True experimental pre-post study included 6 men post CABG participating in a phase II cardiac rehabilitation (CR) with age $\leq 65$ years old, ejection fraction $\geq 40 \%$, no heart failure, no valve disease. Each group had 3 participants. HIIT group exercise at 80-90\% Heart Rate Reserve (HRR) followed by $60-70 \%$ HRR active rest periods, MCT group exercised at 60-80\% HRR. Both groups trained 3 days/ week for 4 weeks. FC measured at baseline and after 4 weeks of rehabilitation. FC was assessed by maximal exercise testing through indirect VO2 max measurement.
\end{abstract}

Results: After training, FC increased significantly in both group HIIT: 0,98 $\pm 0,48$ METs $(8.07 \pm 1.51$ METs to 9.05 \pm 1.21 METs), $\mathrm{p}=0.03$ and MCT : $0,79 \pm 1,03$ METs (5.74 \pm 2.24 to $6.53 \pm 1.69 \mathrm{METs}), \mathrm{p}=0.04)$. Differences in FC improvement between the two groups are $\mathrm{p}=0.792$.

Conclusion: HIIT exercise had no difference with MCT in increasing FC in patients post CABG.

Keywords: $C A B G$, cardiac rehabilitation, continuous moderate training, functional capacity, highintensity interval training 


\section{ABSTRACT}

Pendahuluan: Peningkatan kapasitas fungsional akan menurunkan angka kematian. Latihan aerobik direkomendasikan untuk meningkatkan kapasitas fungsional, akan tetapi bukti mengenai intensitas latihan yang paling efektif untuk meningkatkan kapasitas fungsional pada populasi pasca Bedah Pintas Arteri Koroner (BPAK) masih terbatas. Tujuan penelitian ini untuk mengetahui perbandingan efek Latihan aerobik Interval Intensitas Tinggi (LIIT) dengan Latihan aerobik Kontinu Intensitas Sedang (LKIS) terhadap peningkatan kapasitas fungsional populasi pasca BPAK.

Metode: Rancangan true eksperimental pre-post test dilakukan pada subjek pria pasca BPAK yang memasuki rehabilitasi jantung fase II, usia $\leq 65$ tahun, fraksi ejeksi $\leq 40$, tidak terdapat gagal jantung ataupun penyakit katup. Kelompok LIIT berlatih dengan intensitas latihan inti $80-90 \%$ Heart Rate Reserve (HRR) diselingi periode pemulihan aktif dengan intensitas $60-70 \% \mathrm{HRR}$, sedangkan kelompok LKIS berlatih dengan intensitas kontinu $60-80 \%$ HRR. Kedua kelompok berlatih $3 x /$ minggu selama 4 minggu. Kapasitas fungsional awal diukur sebelum dan setelah program, dinilai dengan uji latih maksimal menggunakan pengukuran VO2 maksimal secara tidak langsung

Hasil: Kapasitas fungsional meningkat signifikan pada kedua kelompok. Kelompok LIIT : $0.98 \pm 0.48$ METs $(8.07 \pm 1.51$ METs menjadi $9.05 \pm 1.21$ METs), $\mathrm{p}=0.03$ dan LKIS : $0.79 \pm 1.03$ METs $(5.74 \pm 2.24$ menjadi 6.53 \pm 1.69 METs), $\mathrm{p}=0.04$. Perbedaan peningkatan kapasitas fungsional kedua kelompok $\mathrm{p}=0,79$.

Kesimpulan: Tidak terdapat perbedaan antara LIIT dan LKIS dalam meningkatkan kapasitas fungsional pasien pasca BPAK.

Keywords: BPAK, kapasitas fungsional, latihan aerobik intensitas tinggi, latihan aerobik kontinu intensitas sedang, rehabilitasi jantung.

Corresponding details:

\section{Dini Fitriani}

Email: dr.dinifitriani@gmail.com

Rumah Sakit Hasan Sadikin J1. Pasteur No.38, Pasteur, Kec. Sukajadi, Kota Bandung, Jawa Barat 40161

\section{INTRODUCTION}

Atherosclerosis is a chronic inflammatory disease of the arteries. Accumulation of low- density lipoprotein and remnant lipoprotein particles and an active inflammatory process in focal areas of arteries is considered a primary cause of atherosclerotic cardiovascular disease (ASCVD) resulting in heart attacks and stroke. ${ }^{1}$ Survey data from Sample Registration System (SRS) 2014 showed that coronary artery disease (CAD) was the second highest mortality cause in all ages after stroke, which is $12,9 \% .^{2}$ Coronary artery bypass grafting (CABG) is one of the CAD interventions that create a new coronary artery to bypass the clotted or narrowed artery. Indications of CABG are ST Elevated Myocardial Infarction, the right coronary artery stenosis $\geq 50 \%$, moderate 
or high complexity for percutaneous coronary intervention (PCI), and or three coronary arteries stenosis $\geq 70 \%{ }^{3,4}$

Aerobic exercise is recommended for patients with CAD as the main program in phase II cardiac rehabilitation as secondary prevention to modified the risk factor and decrease recurrent angina. ${ }^{5,6,7}$ Aerobic exercise in cardiac rehabilitation would increase functional capacity (FC) 10,5-48,2\% without causing any serious complications. Functional capacity was an independent predictor for higher risk of cardiopulmonary complication. CAD patients who undergo $\mathrm{CABG}$ procedure had the lowest (FC) compared to patients undergoing PCI and post-myocardial infarction patients. $8,9,10,11,12$

American College of Sports Medicine (ACSM) recommended Moderate Continuous Intensity Training (MCT) 40-80\% heart rate reserve (HRR) prescribed for cardiac patients. ${ }^{13}$ Although existing aerobic exercise prescription is safe and optimal, the researcher is interested in highintensity interval training (HIIT) because it has been proven to be better for stable CAD patients. Aerobic exercise even in HIIT will be safe for stable CAD patients by a pre-participation and risk-assessment evaluation that required taking into account age, pre-infarction level of activity, and testing their maximal exercise capacity throgh exercise testing. The exercise testing permits an assessment of any abnormal cardiovascular responses that might not otherwise be apparent during usual daily activities. ${ }^{14,15,16}$ Some study was done for stable CAD patients that did not specify for post-CABG patients, including the stable $\mathrm{CAD}$ patients that did not undergo revascularization and the patients who did revascularization with PCI. The study showed that HIIT was superior to MCT in increasing the $\mathrm{FC}$ in stable $\mathrm{CAD}$ patients. ${ }^{8,17,18} \mathrm{CABG}$ procedure has a higher risk than PCI, but the revascularization is complete; therefore, the potency of the exercise response is better. ${ }^{8}$ HIIT study has been done in post-CABG patients in Europe, even though there has been the previous study, but there is two difference factors: (1) gender (2) ethnic. ${ }^{19}$ The study subjects were both men and women, but the FC between them is different. The variation of atherosclerosis rate among different ethnic showed that Asians have a higher risk than Caucasians. Asians have narrowed blood vessels, a more rigid artery, and lower endothelial respond compared to Caucasians. The blood vessel remodeling will be affected by those primary defects. ${ }^{20,21}$ The purpose of this study is to compare the difference FC between HIIT and MCT in post-CABG patients who participate in phase II cardiac rehabilitation.

\section{METHODS}

Subject requirement

The inclusion criteria of this study were PostCABG patients admitted to phase II cardiac rehabilitation, men $\leq 65$ years old, and ejection fraction $\geq 40 \%$. Exclusion criteria were patients that included in high-risk stratification based on American Association of Cardiovascular and Pulmonary Rehabilitation (AACVPR), and did not have a comorbidity that might interfere treadmill or leg ergocycle exercise, heart failure, CCS II-IV angina criteria, cardiac valve disease, massive pleural effusion, did not complete the run-in period (complete $\geq 4$ of 6 early exercise session with MCT 40-60\% heart rate reserve (HRR), had a cardiac complication in the run-in period or maximal exercise test and do not want to participate in the study. 
Functional Capacity Examination

Potential subjects were recruited from all patients enrolled in the phase II CR program at Hasan Sadikin Hospital Bandung cardiac center's gymnasium. After the run-in period, informed consent was given for the eligible patients and, if attained, a maximal exercise stress test using Ganshorn treadmill or leg ergocycle (ergosana) without respiratory gas analysis with Bruce or modified Bruce protocol. The speed and inclination of the treadmill test were increased every 3 minutes until the subject felt exhausted (Borg scale above 17). The workload in leg ergocycle is quantified in watt. Functional capacity was determined based on indirect $\mathrm{VO}_{2}$ max estimation by converting treadmill test duration into a metabolic equivalent (MET). The stress test was completed under the supervision of a trained doctor. During follow up testing, the supervisor of the maximal exercise testing was blinded to study group assignment. The stress test will be redone after the fifth week after the subject completes the exercise program. The pre and post-test functional capacity obtained than will be analyzed to find if there is a significant increase in the group and then compared with the other group.

\section{Exercise Training}

The subjects were randomized using a lottery for four weeks of CR using either the HIIT or MT method of exercise training on treadmill (Valiant ${ }^{\circledR C P E T)}$ or leg ergocycle (Monark Ergomedik 828E). The aerobic exercise training conducted three days a week for four weeks. Patients assigned to MCT completed 5 minutes of active warm-up, 30 minutes of aerobic training in intensity at $60 \%$ to $80 \%$ of heart rate reserve (HRR) exercise intensity was prescribed at $60 \%$ to $80 \%$ of heart rate reserve throughout, and 5 minutes of active cool-down. Patients assigned to
HIIT also completed 5 minutes of active warmup, followed by 3 minutes of training at $60 \%$ to $70 \%$ of HRR and four higher-intensity work intervals of 4 minutes each, set at an intensity corresponding to $80 \%$ to $90 \%$ of HRR. A 3-minute active recovery period set at an intensity of $60 \%$ to $70 \%$ of HRR followed each of the four higher- intensity intervals. Following the last 3-minute recovery interval, patients completed a 4-minute active cool-down period. In the first assessment, subjects who did not have balance disorders or musculoskeletal pain or problem in the leg area were given treadmill exercises. While the subjects who had these complaints used leg ergocycle. During exercise training, the doctor that accompanies and patients in the HIIT and MCT groups were allowed to adjust treadmill and leg ergocycle workloads to maintain exercise training heart rate within prescribed levels. During the run-in period and intervention programs, heart rate during exercise training was monitored by telemetry (Valiant ${ }^{\circledR}$ ) dan oxygen saturation (Schiller ${ }^{\circledR}$ ) is provided to each patient. Aerobic exercise at home was not permitted for all patients in the study.

\section{Drop-out}

The subject that does not come more than four exercise sessions, subject that get muscle ischemia, unstable hemodynamic, new cardiac infarct, angina, significant arrhythmia.

\section{Statistical Analysis}

This study is a true experimental study with a pre-test and post-test. This study had been reviewed and approved by the research and ethics review committee of Hasan Sadikin Hospital Bandung, Indonesia. All of the subjects have given informed consent. With a two-tailed t-test for independent samples at a power of 
0.7 and $\alpha=0.5$, three subjects for each group had to enroll.

The Power was low because the data obtained from the last year that there was predicted the subjects with only CABG problems without heart valve problems, and heart failure was difficult to find and almost of the potential subject also stayed at the other town. The actual stastitical analysis performed takes G*power

Normality data were analyzed with Shapiro Wilk using SPSS 20 version for windows, an increase of the functional capacity between pre and post-test in each group was analyzed using paired t-test with the statistical significance was based on $\mathrm{p} \leq 0.05$.

\section{RESULTS}

20 Post-CABG patients meets the inclusion criteria (history taking, physical examination, functional test)

Data collection (echocardigraphy, angiography)

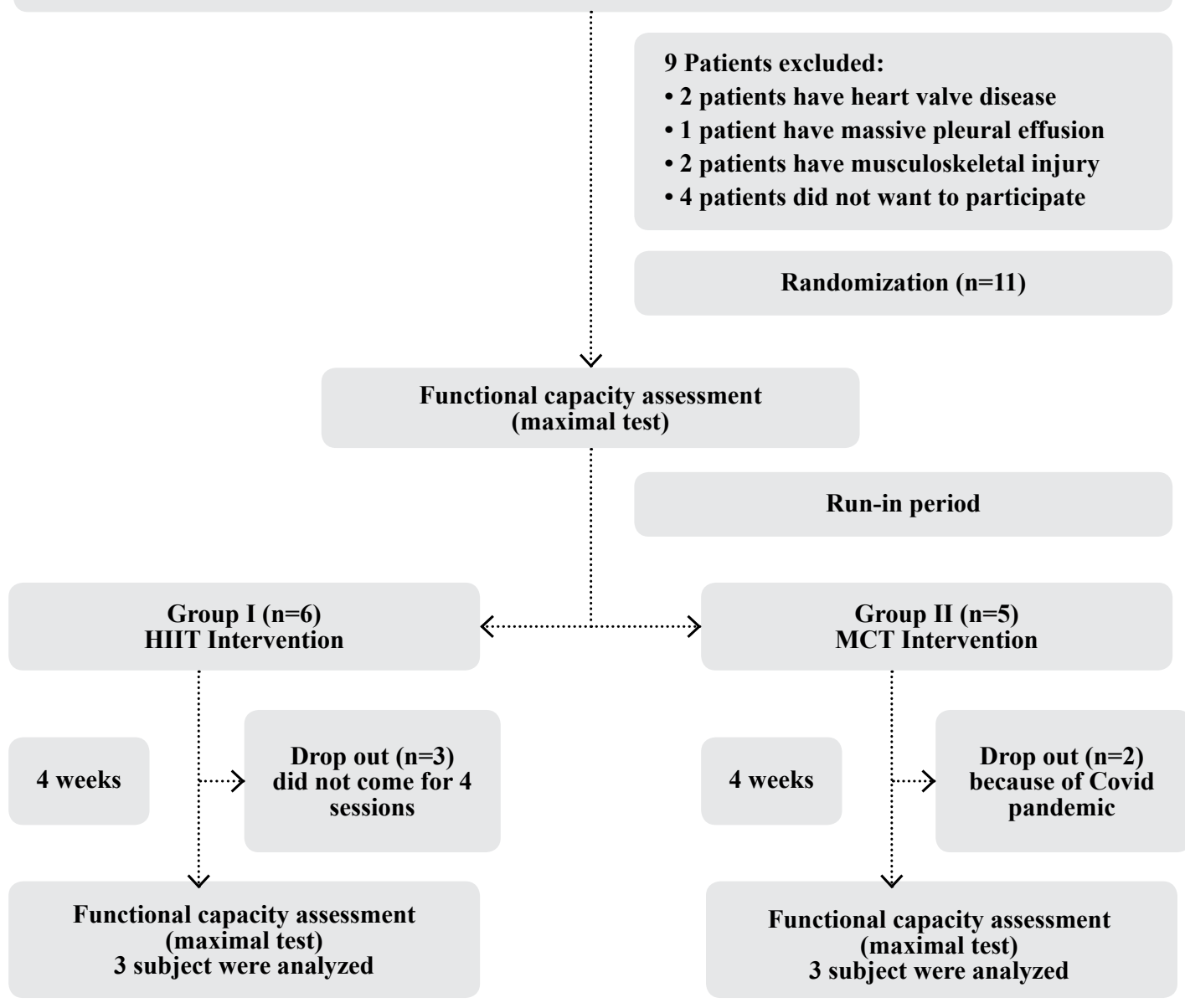

Figure 1. Flow of participants through the trial 
The Patients recruited between November 2019-February 2020. Overall, eleven subjects were randomized (HIIT: $\mathrm{n}=6$, MCT: $\mathrm{n}=5$ ). The final participants of this study were six subjects (HIIT: $n=3$, MCT $n=3$ ) (figure 1). The baseline characteristics of the two groups were no significally different, except for BMI (Table I). The baseline functional capacity in the HIIT group was $8.07 \pm 1.51 \mathrm{MET}$, and the MCT group was $5.74 \pm 2.24$. There were no major complications or cardiac events during the study period. Five subjects were drop out during the program, three subjects in the HIIT group because they did not come for four sessions, two patients in the MCT group resign because of the COVID pandemic. The subjects in both groups completed twelve exercise sessions, and none of the subjects had changed on the beta-blocker dosage. The subjects in the HIIT group could do the high-intensity exercise $80-90 \%$ HRR for three to four-minute continue with active recovery 60-70 HRR. The subjects in MCT done the aerobic exercise with intensity $60-70 \%$ HRR constantly as the more common exercise in CR. In both groups, there were no major complications or cardiac events during the study period.

Tabel 1. Baselines characteristics of participants

\begin{tabular}{|c|c|c|c|}
\hline Characteristics & $\begin{array}{l}\text { HIIT Group Average } \pm \text { SD } \\
\text { /n (\%) } \\
(\mathrm{n}=3)\end{array}$ & $\begin{array}{c}\text { MCT Group } \\
\text { Average } \pm \text { SD / } \mathrm{n}(\%) \\
(\mathrm{n}=3)\end{array}$ & $\mathrm{p}$ value \\
\hline Age (years) & $55.67 \pm 6.43$ & $55.33 \pm 4.04$ & $0.94^{\$}$ \\
\hline DM & $1(33)$ & $0(0)$ & $1.00^{*}$ \\
\hline HT (Hypertension) & $2(67)$ & $3(100)$ & $1.00^{*}$ \\
\hline Dyslipidemia & $1(33)$ & $3(100)$ & $0.40^{*}$ \\
\hline Smoking & $2(67)$ & $3(100)$ & $1.00^{*}$ \\
\hline Body mass index $\left(\mathrm{kg} / \mathrm{m}^{2}\right)$, & $23.26 \pm 4.07$ & $31.87 \pm 8.65$ & $0.05^{\varsigma * *}$ \\
\hline Systolic blood pressure $(\mathrm{mmHg}$ & $133.33 \pm 5.77$ & $135 \pm 13.23$ & $0.85^{\$}$ \\
\hline Diastolic blood pressure (mmHg) & $76.67 \pm 5.77$ & $80.00 \pm 10.00$ & $0.64^{\$}$ \\
\hline Heart Rate ( $\mathrm{x} /$ minute), average & $69.33 \pm 5.13$ & $73.67 \pm 6.66$ & $0.42^{\$}$ \\
\hline \multicolumn{4}{|l|}{ Drugs: } \\
\hline$A C E$ inhibitor or $A R B$ & $1(33)$ & $1(33)$ & $1.00^{\$}$ \\
\hline$B$-Adrenergik blocker & $3(100)$ & $3(100)$ & - \\
\hline Calcium channel blocker & $0(0)$ & $2(67)$ & $0.40^{*}$ \\
\hline Lipid lowering & $3(100)$ & $3(100)$ & - \\
\hline Diuretic & $1(33)$ & $0(0)$ & $1.00^{*}$ \\
\hline \multicolumn{4}{|l|}{ Antiplatelet: } \\
\hline Aspirin & $3(100)$ & $3(100)$ & - \\
\hline Clopidogrel & $1(33)$ & $1(33)$ & $1.00^{*}$ \\
\hline Functional capacity (METs), average & $8.07 \pm 1.51$ & $5.74 \pm 2.24$ & $0.21^{\$}$ \\
\hline
\end{tabular}

$\$$ Unpaired t-test; *Uji Fisher Exact, ** significantly difference $(\mathrm{p} \leq 0.05)$ 
Outcomes

Figure 2 showed the increase in functional capacity using Bruce protocol maximal exercise testing. Modified Bruce using a treadmill and ergometer protocol using leg ergocycle after completed the program by both of the groups. The subjects in HIIT group have increase in functional capacity 0,39 METs, 1,26 METs, and
1,26 METs, In the MCT group the increase were 0,42 METs, 0 METs, dan 1,95 METs. Statistical analysis using paired-t-test show a significant increase in functional capacity after given the exercise in both groups (HIIT $\mathrm{p}=0.03$, MCT $\mathrm{p}$ $=0.04)$ (table 2). Unpaired t-test show there is no difference between the increase in functional capacity in HIIT and MCT group $(p=0.79)$

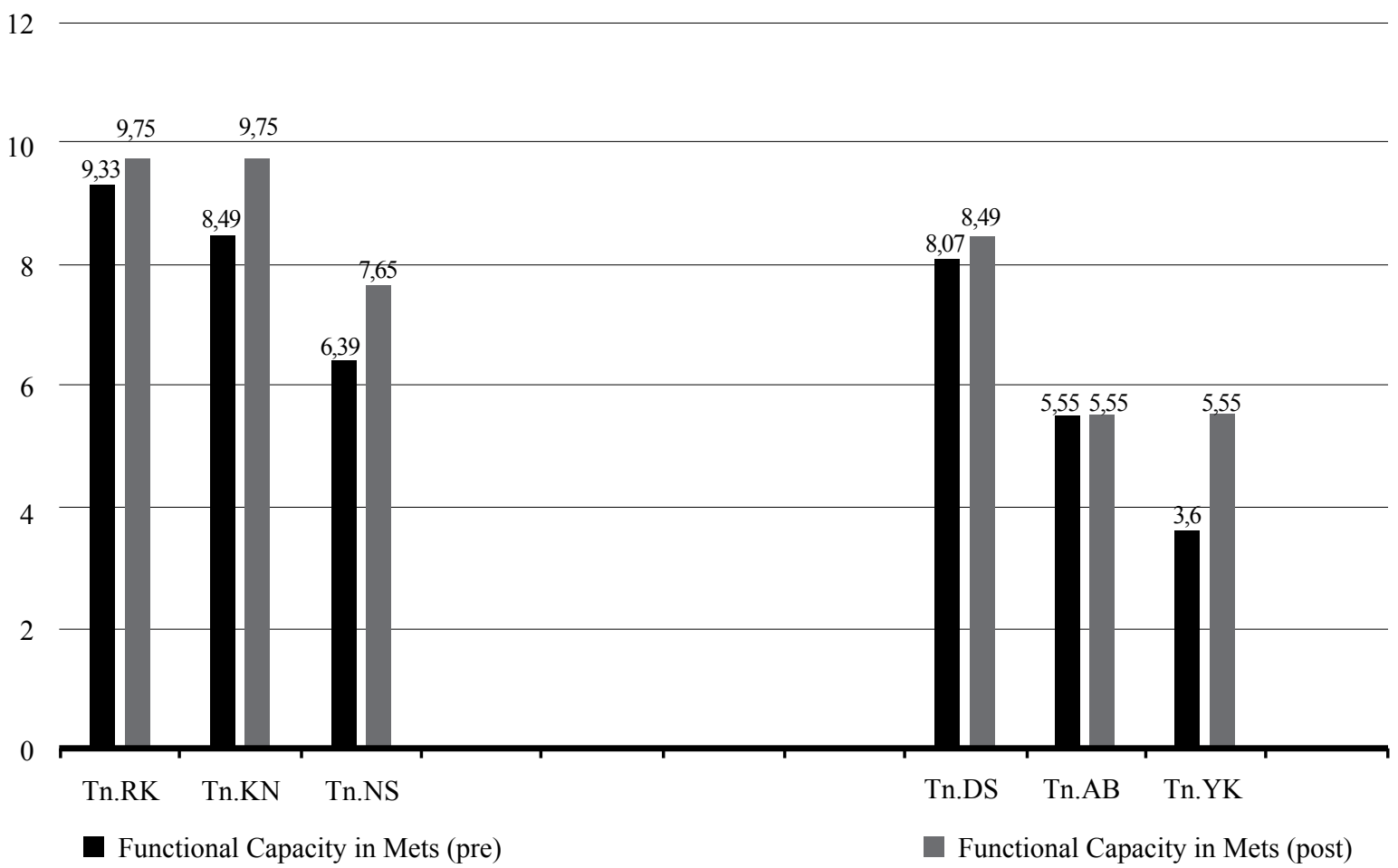

Figure 2. Difference in Functional Capacity in HIIT and MCT group

Table 2. Difference in functional capacity between Pre and Post intervention In HIIT and MCT group

\begin{tabular}{ccccccc}
\hline & \multicolumn{3}{c}{ HIIT $(\mathrm{n}=3)$} & \multicolumn{3}{c}{ MCT (n=3) } \\
& Pre & Post & $\mathrm{p}$ & Pre & Post & P \\
\hline $\begin{array}{c}\text { Functional capacity } \\
\text { (METs) }\end{array}$ & $8.07 \pm 1.51$ & $9.05 \pm 1.21$ & $0.03^{*}$ & $5.74 \pm 2.24$ & $6.53 \pm 1.69$ & $0.04^{*}$ \\
\hline
\end{tabular}

* t-paired test 
Table 3. Difference in functional capacity between HIIT and MCT group

\begin{tabular}{ccc}
\hline Group & Difference METs, AverageSD & P value \\
\hline HIIT $(\mathrm{n}=3)$ & 0.980 .48 & $0.79^{\text {s }}$ \\
MCT $(\mathrm{n}=3)$ & 0.791 .03 & \\
\hline
\end{tabular}

${ }^{\$}$ Unpaired t-test

\section{DISCUSSION}

The average age of the subject in the study was $55.67 \pm 6.43$ in the HIIT group and $55.33 \pm 4.04$ in the MCT group, with the range 51-63 years old. This finding was same with the data collected by Ariaty et all the average age of patient undergo CABG operation in Hasan Sadikin hospital until 2017 is 59 years old with the range is 33-79 years old..$^{22}$ This study had youngest average age compare to the others study, Keteyian study ( $60 \pm$ 7 year old in the HIIT group and $58 \pm 9$ in the MCT group), Rognmo $(62.9+11.2$ years old for the HIIT group and $61.2 \pm 7.3$ years old for the MCT group). ${ }^{17,18,19}$ Functional capacity will decrease $5-10 \%$ every decade. Then the age difference will interfere with the functional capacity achieved. ${ }^{20}$ This study narrowed the range of age to 65 years old because atherosclerosis will increase in people older than sixty-five years old. Vascular endothelium functional capacity, which response to exercise also lower. ${ }^{23}$

One subject in the HIIT group has diabetes, but there has no subject in the MCT group has diabetes. Cardiac rehabilitation in the diabetes population will increase functional capacity but no as high as a non-diabetes population in the same baseline functional capacity. ${ }^{24}$ Because there was a diabetes subject in the HIIT population, maybe the subject would interfere with the increase of the functional capacity in that group.

The average BMI in the HIIT group was $23.26+4.07$ and $31.87+8.65$ in the MCT group. There is a significant difference between the two groups with $p$-value $\leq 0.05$. Body mass index is one of the simplest and the most frequently used indicator for measure overweight and obesity in adults. Functional capacity depends on the cardiovascular system, respiratory function, hematology condition, and exercise capacity. Obesity is related to the cardiovascular and respiratory systems. Someone with overweight has lower functional capacity significantly compare to others with healthy body weight. ${ }^{25}$

The HIIT group had one subject with obesity grade 1. The MCT group had one with first type 1 obesity and one with type 2 obesity, so the difference of the BMI can interfere with the functional capacity of both groups.

The Aerobic capacity very depends on BMI, because aerobic capacity is count per unit body weight. The increase in BMI will cause lower aerobic functional capacity. Even though oxygen capacity is stated in liter oxygen consumed per kilograms body weight, different body composition will cause different oxygen consumption. The higher percentage of body fat has lower maximum oxygen consumption, 
meanwhile higher muscle mass will increase aerobic capacity. The obese subjects had a total body and visceral fat higher than subjects that had a slim body. The more obese someone, the functional capacity will be lower. ${ }^{26}$ Aerobic exercises that have been done by obese patients increase insulin stimulation, increasing glucose uptake in the whole body that increases functional capacity. ${ }^{27}$ Naqvi et al. found the phase II cardiac rehabilitation effective in increasing functional capacity on obese subjects compared to nonobese subjects in the post-CABG patient, but the mechanism is still unclear. ${ }^{28}$ Contrary to the study by Davidson et al., an increase in functional capacity in the obese population was lower than that of non-obese. The smaller increase in the obese population's functional capacity was caused by the lower elasticity of the large artery, which caused augmented aorta afterload. ${ }^{26}$

The functional capacity classification in men 50- 59 years is outstanding functional capacity $\geq 14$ METs, good functional capacity 11-14 METs, sufficient 8-11 METs, low 6-8 METs, and poor $<$ METs. ${ }^{29}$ The study by Smith et al. found that $\mathrm{CABG}$ patients with functional capacity $<5$ METs before CABG surgery were correlated with thirty days after surgery mortality rate after CABG surgery.30 The subjects in this study had functional capacity 6.39-9.75 METs in the HIIT group and 3.6-8.07 METs in the MCT group, there is one subject that had functional capacity $\leq 5$ METs that became subject in the MCT group, meanwhile subjects that have METs more than 8 METs is two subjects in the HIIT group, and one subject in the MCT group. Low functional capacity in this study was similar with the statement from Ades et al that early functional capacity in post-CABG revascularization patients was low because of the post-surgery stress, hospitalization, and reduction in physical activity, even though some of the subjects had better early-stage functional capacity expected from higher regular physical activity rather than before CABG. Physical activity will influence functional capacity. ${ }^{11}$

This study's outcome in statistical analysis using an unpaired t-test in $95 \%$ confidential interval showed there is no significant difference in the increase of the functional capacity between two groups $(\mathrm{P}>0.05)$. The functional capacity in this study was measured after the run-in period, so the functional capacity increase was genuine originate from HIIT exercise.

This study unable to compared with another study because of the small amount of the sample. The study by Rognmo et al in stable CAD population had eight subjects in the HIIT group, and nine subjects in the MCT group showed that there was a significant difference $(\mathrm{p} \leq 0.05)$ between the groups with the increase of the functional capacity was 1.71 METs in the HIIT group and 0.77 METs in the MCT group. The study by Moholdt et al in the post-CABG population show that there is no significant functional capacity difference between HIIT and MCT group. This study was done for four weeks, similar to the study done by Moholdt et al. Meanwhile, Rognmo et al. gave ten weeks of exercise program. ${ }^{19,31}$ Systematic review by Hannan et al showed that HIIT was more superior to that of $\mathrm{MCT}$ in $\mathrm{CAD}$ population that participate in cardiac rehabilitation with a standardized mean difference with the difference in the functional capacity being $0.97 \mathrm{METs}(\mathrm{ml} /$ $\mathrm{kg}$ /minute) between the groups. The increase in functional capacity in stable CAD shows a significant difference after seven to twelve weeks of exercise. ${ }^{14}$ The functional capacity increase in 
this study statistically did not show a difference increase between the groups $(\mathrm{p}=0.79)$. However, even though the exercise gave only four weeks, the HIIT group's functional capacity increased already showed a higher increase than the MCT group (table 2). This study showed the acute difference in the functional capacity between the HIIT group and the MCT group, which is 0.19 METs. The groups showed a significant increase in functional capacity after the program, which is $\mathrm{p}=0.03$ in the HIIT group, and $\mathrm{p}=0.04$ in the MCT group. The functional capacity increase was similar to a study done by Goldberg et al. that shows in short-term, aerobic exercise three times a week for four weeks can reduce the artery stiffness, therefore vasodilating the blood vessel in lower extremities. ${ }^{32}$ The increase of functional capacity is caused by cardiovascular and also peripheral adaptation that is stimulated by aerobic exercise. High-intensity interval training proven to stimulate higher shear stress that provides a higher vasodilatation effect that is higher than moderate continuous training. ${ }^{3}$

The functional capacity increase has clinical advantages, as stated in previous studies. Lower functional capacity is related to a higher risk for premature mortality that caused by all factors, especially cardiovascular diseases, and have worst cardiac metabolic in CAD patient. ${ }^{34,35}$ Study done by Keteyian et al showed that every increase of 0.28 METs $(1 \mathrm{ml} / \mathrm{kg} /$ minute in VO2 peak) would reduce mortality risk factor by $15 \%$ in both men and women with CAD.${ }^{36}$ Gander et al stated that every 1 METs increase would reduce $20 \%$ CAD risk factor. ${ }^{37}$ Functional capacity increase, hyperlipidemia, diabetes in CAD patients are related to higher life expectancy in this group subjects. Cardiac and non-cardiac comorbidity also lower (except in hyperlipidemia group) significantly in the group that has higher functional capacity. The increase in functional capacity in patients with hypertension is the strongest factor in life expectancy than other risk factors. The Functional capacity is the strongest and modified modifiable risk factor correlated with long term mortality rate. The functional capacity increase also correlated with lowering recur myocardial infarction, atrial fibrillation, stroke, heart failure, and hypertension. ${ }^{34,38,39}$

The increase of functional capacity in the HIIT group in this study was that $0.98 \pm 0.48$ MET, similar to the study by Moholdt et al (0.94 METs). However, lower than six others research that had been done, that was Keteyian et al (1.02 METs), Prado et al (1.25 METs), Jaureguizar et al (1.28 METs), Rognmo et al (1.71 METs), Gazella et al (1.68 METs), Kim et al. (1.8 METs) dan Abdelhalem et al (2 METs), but the functional capacity increase in MCT group $(0.79 \pm 1.02$ METs) was higher compared to the previous study, that were Moholdt et al (0.65 METs) which is also four weeks study, and similar to Rognmo et al (0.77 METs) that have done ten weeks study, Jaureguizar et al (0.71 MET) that done ten weeks study, higher than Keteyian et al (0.48 METs). A higher functional capacity increase in the MCT group in this study may be because the baseline functional capacity was lower compared to the previous study, which is $5.74+2.24$ METs. ${ }^{17,18,19,40,41,42,43,44}$ Figure 2 show functional capacity increase was highest inpatient with lowest baseline functional capacity (3.6 METs). Higher baseline functional capacity showed the cardiac fitness of the subject before start cardiac rehabilitation. The study by Tiksnadi et al and Prado et al stated that lower baseline functional capacity before exercise would increase higher functional capacity. ${ }^{9,12}$ The higher increase in 
functional capacity in the MCT group in this study compared to other previous studies became one of the factors that caused no significant difference between the HIIT and the MCT group.

Limitation of this study was: Since our study's power was low $(71,07 \%)$, we should take precaution if we want to implement it. Higher power is need for further study.

\section{CONCLUSION}

Functional capacity increase in high-intensity interval training had no difference compared to moderate continuous intensity aerobic training in patients post CABG. Moderate continuous intensity aerobic training still remain the better choice for short term exercise in phase II CR because more simple for supervised and lower precaution.

\section{ACKNOWLEDGMENTS}

Special thanks to the patients and staff at Hasan Sadikin Hospital Bandung for the excellent cooperation and dr. Lintang for collecting the data.

\section{REFERENCES}

1. Pahwa R, Jialal L. Atherosclerosis. StatPearls.2019. Available from:htpps//:www. nvbi.gov/books/NBK.507709.

2. Kementrian kesehatan RI. Penyakit Jantung Penyebab Kematian Tertinggi, Kemenkes ingatkan CERDIK. 2017. Available at http:// www.depkes.go.id. Accessed November 20183.

3. Alexander JH, Smith PK. Coronaryartery bypass grafting. $\mathrm{N}$ Engl $\mathrm{J}$ Med. 2016;374(20):1954-64.

4. Rashid MA, Edwards D, Walter FM, Mant J. Medication Taking in Coronary Artery Disease. Ann Fam Med. 2014;224-32.

5. Mampuya WM. Cardiac rehabilitation past, present, and future: an overview. Cardiovasc Diagn Ther. 2012;2(1):38-49.

6. Task A, Members F, Piepoli MF, Hoes AW, Germany CA. European Guidelines on cardiovascular disease prevention in clinical practice. The Sixth Joint Task Force of the European Society of Cardiology and Other Societies on Cardiovascular Disease Prevention in Clinical Practice. Atherosclerosis. 2016;252:207-74

7. Aikawa P, Kondo NN, Guillermo M, Gomes PR, da silva PF. Physical Training Programs after Coronary Artery Bypass Grafting. IntechOpen. 2016:149-62

8. Lan C, Chen S-Y, Lai J-S. Exercise Training for Patients After Coronary Artery Bypass Grafting Surgery. Acute Coronary Syndrome. 1st ed. Rijeka: IntecOpen;2012.

9. Prado DML, Rocco EA, Silva AG, Silva PF, Lazzari JM, Assumpção GL, et al. The influence of aerobic fitness status on ventilatory efficiency in patients with coronary artery disease. Clinics. 2015;70(1):46-51.

10. Licker M, Schnyder JM, Frey JG, Diaper J, Cartier V, Inan C, et al. Impact of aerobic exercise capacity and procedure-related factors in lung cancer surgery. Eur Respir J. 2011;37(5):1189-98. 
11. Ades PA, Savage PD, Brawner CA, Lyon CE, Ehrman JK, Bunn JY, et al. Aerobic capacity in patients entering cardiac rehabilitation. Circulation. 2006;113(23):2706-12.

12. Tiksnadi BB, Aziz M, Chesario MS, Renaldi M, Triadi A, Sastradimaja BS. Functional Capacity Improvement Related to Inflammatory Marker Reduction After Phase II Cardiac Rehabilitation Program in Postrevascularization Coronary Artery Disease Patients Keywords : cardiac rehabilitation program ; functional capacity ; hs-CRP. Acta Cardiol Indones. 2018;5(1):19-34.

13. Keteyian SJ. Exercise Prescription for Patient with Cardiac, Peripheral, Cardiovascular, and Pulmonary Diseasse. In: Riebe D, Ehrman, JK, Ligouri G, editors. ACSM's Guidlines for Exercise Testing and Prescription. 10th ed. Philadelphia: Wolters Kluwer; 2018

14. Pellicia A, Sharma S, Gati S, Sabiha B. 2020 ESC Guidelines on sports cardiology and exercise in patient with cardiovascular disease. Eur Heart J. 2020:ehaa 605

15. Ambrosetti M, Abreu A, Corra U, Davos C, Hansen D. Secondary prevention through comprehensive cardiovascular rehabilitation: From knowledge to implementation, 2020 update. A position paper from the Secondary Prevention and Rehabilitation Section of The European Association of Preventive Cardiology. Eur J Prev Cardiol. 2020

16. Rognmo Ø, Hetland E, Helgerud J, Hoff J, Slørdahl SA. High intensity aerobic interval exercise is superior to moderate intensity exercise for increasing aerobic capacity in patients with coronary artery disease. Eur J Cardiovasc Prev Rehabil. 2004;11(3):21622.
17. Keteyian SJ, Hibner BA, Bronsteen K, Kerrigan D, Aldred HA, Reasons LM, et al. Greater improvement in cardiorespiratory fitness using higher-intensity interval training in the standard cardiac rehabilitation setting. J Cardiopulm Rehabil Prev. 2014;34(2):98105.

18. Moholdt TT, Amundsen BH, Rustad LA, Wahba A, Løvø KT, Gullikstad LR, et al. Aerobic interval training versus continuous moderate exercise after coronary artery bypass surgery: A randomized study of cardiovascular effects and quality of life. Am Heart J. 2009;158(6):1031-7.

19. Hoffman M. Adaptations to Endurance Training. In: Frontera W, editor. Exercise in Rehabilitation Medicine. 2nd ed. United States of America : Human Kinetics; 2006. p. 13-23.

20. Petrofsky JS, Alshammari F, Lee H, Hamdan A, Yim JE, Shetye G, et al. Reduced endothelial function in the skin in Southeast Asians compared to Caucasians. Med Sci Monit. 2012;18(1):1-8.

21. Ariati GM, Sudjud reza W, Sitanggang RH. Angka mortalitas pada pasien yang menjalani bedah pintas koroner berdasar usia, jenis kelamin, left ventrikular ejection fraction, cross clamp time, cardio pulmonary bypass time, dan penyakit penyerta. J Anastesi Perioper. 2017;5:3.

22. Berlowitz M, Brown DL. The Clinical Manifestations of Plaque Ruptures. In: Brown DL, editor. Cardivascular Plaque Rupture. New York: CRC Press; 2002:191-207.

23. Clair MS, Mehta H, Sacrinty M, Johnson $\mathrm{D}$, Robinson K. Clinical Investigations Effects of Cardiac Rehabilitation in Diabetic 
Patients: Both Cardiac and Non-cardiac Factors Determine Improvement in Exercise Capacity Clinical Cardiology. 2014;238:2338.

24. Shazia SM, Badaam KM, Deore DN. Assessment of aerobic capacity in overweight young females : A cross - sectional study. Int J Appl Basic Med Res. 2015;5(1):18-20.

25. Davison K, Bircher S, Hill A, Coates AM, Howe PRC, Buckley JD. Relationships between Obesity , Cardiorespiratory Fitness, and Cardiovascular Function. Journal of Obesity. 2010;1;1-7.

26. Gan SK, Kriketos AD, Ellis B, Thompson $\mathrm{CH}$, Kraegen EW, Chisholm DJ. Changes in Aerobic Capacity and Visceral Fat but not Myocyte Lipid Levels Predict Increased Insulin Action After Exercise in. Am Diabetes Assoc. 2003;26(6):1706-13.

27. Naqvi M, Khan MS, Perwaiz S, Ibrahim Q, Khan MW, Khan TY. Comparative analysis on the efficacy of aerobic capacity in cardiac rehabilitation obese and non-obese phase ii patient. Int physiother. 2019;6(2):64-9.

28. Arena R. Clinical Exrecise Testing. In: Lupash E, Ehrman JK, editors. ACSM's Guidlines for Exercise Testing and Prescription. 9th ed. Baltimore, Philadelphia: Lippincolt, Williams and Wilkins; 2014. p. 114-60.

29. Smith JL, Verrill TA, Boura JA, Sakwa MP, Shannon FL, Franklin BA. Effect of cardiorespiratory fitness on short-term morbidity and mortality after coronary artery bypass grafting. Am J Cardiol. 2013;112(8):1104-9.

30. Rognmo O, Moholdt T, Bakken H, Hole T, Mølstad P, Myhr NE, et al. Cardiovascular
Risk of High-Versus Moderate-Intensity Aerobic Exercise in Coronary Heart Disease Patients. Circulation. 2012;126(12):1436-40.

31. Hannan AL, Hing W, Climstein M, Coombes JS, Byrnes J, Furness J. High-intensity interval training versus moderate-intensity continous training within cardiac rehabilitation: a systematic review and meta-analysis. J Sport Med. 2018;9:1-17.

32. Goldberg MJ, Boutcher SH, Boutcher YN. The effect of 4 weeks of aerobic exercise on vascular and baroreflex function of young men with a family history of hypertension. $\mathrm{J}$ Hum Hypertens. 2012;26(11):644-9.

33. Cassidy S, Thoma C, Houghton D, Trenell MI. High-intensity interval training: a review of its impact on glucose control and cardiometabolic health. Diabetologia. 2017; 60(1):7-23.

34. Nichols S, Taylor C, Page R, Kallvikbackabennett A, Nation F, Goodman T, et al. Is Cardiorespiratory Fitness Related to Cardiometabolic Health and All-Cause Mortality Risk in Patients with Coronary Heart Disease ? A CARE CR Study. 2018.

35. Dumke CL. Health-Related Physical Fitness Testing and Interpretation. In: D. Riebe, J. Ehrman GL, editor. ACSM's Guidlines for Exercise Testing and Prescription. 10th ed. Philadelphia: Wolters Kluwer; 2018.

36. Keteyian SJ, Brawner CA, Savage PD, Ehrman JK, Schairer J, Divine G, et al. Peak aerobic capacity predicts prognosis in patients with coronary heart disease. Am Heart J. 2008; 156(2):292-300.

37. Gander JC, Sui X, Hébert JR, Hazlett LJ, Cai B, Lavie CJ, et al. Association of 
Cardiorespiratory Fitness With. Mayo Clin

Proc. 2015; 90(10):1372-9.

38. Mandsager K, Harb S, Cremer P, Phelan D, Nissen SE, Jaber W. Association of Cardiorespiratory Fitness With Longterm Mortality Among Adults Undergoing Exercise Treadmill Testing. 2018;1(6):1-12.

39. Al-mallah MH, Sakr S, Al-qunaibet A. Cardiorespiratory Fitness and Cardiovascular Disease Prevention: an Update. Springer Nat. 2018;20(1):1-7

40. Kim C, Choi HE, Lim MH. Effect of high interval training in acute myocardial infarction patients with drug-eluting stent. Am J Phys Med Rehabil. 2015; 94(10): 879-86.

41. Prado DML, Rocco EA, Silva AG, Rocco DF, Pacheco MT, Silva PF, et al. Effects of continuous vs interval exercise training on oxygen uptake efficiency slope in patients with coronary artery disease. Brazilian J Med Biol Res. 2016;49(2):e4890.
42. Gazella S. Perbandingan Efek Latihan Aerobik Interval Intensitas Tinggi dengan Latihan Aerobik Kontinu Intensitas Sedang terhadap Peningkatan Kapasitas Fungsional Pasien Pasca Intervensi Koroner Perkutan yang Mengikuti Rehabilitasi Jantung Fase II (thesis). Bandung: Padjadjaran University; 2015.

43. Villelabeitia Jaureguizar K, Vicente-Campos D, Ruiz Bautista L, De La Peña CH, Arriaza Gómez MJ, Calero Rueda MJ, et al. Effect of High-Intensity Interval Versus Continuous Exercise Training on Functional Capacity and Quality of Life in Patients with Coronary Artery Disease: A randomized clinical trial. J Cardiopulm Rehabil Prev. 2016;36(2):96- 105.

44. Abdelhalem AM, Shabana AM, Onsy AM, Gaafar AE. High intensity interval training exercise as a novel protocol for cardiac rehabilitation program in ischemic Egyptian patients with mild left ventricular dysfunction. Egypt Hear J. 2018; 70(4): 287-94. 